\title{
The Role of Patent Foramen Ovale Closure in the Secondary Prevention of Cryptogenic Stroke: a Meta-Analysis Report
}

\author{
Sónia P. Pinto Pereira, ${ }^{1 \oplus}$ Alzira Nunes, ${ }^{2}{ }^{\circledR}$ Cristina Santos, ${ }^{1}{ }^{\circledR}$ Scott E. Kasner, ${ }^{3 \oplus}$ José P. L. Nunes ${ }^{1 \oplus}$ \\ Faculdade de Medicina da Universidade do Porto, ${ }^{\text {Porto - Portugal }}$ \\ Centro Hospitalar Universitário São João, ${ }^{2}$ Porto - Portugal \\ University of Pennsylvania, ${ }^{3}$ Philadelphia - USA
}

\section{Abstract}

Background: Patent foramen ovale (PFO) closure has been compared to medical therapy for secondary prevention of recurrent cryptogenic stroke.

Objectives: To produce an updated meta-analysis including only data from the primary analyses of clinical trials and to evaluate the role of PFO closure in the secondary prevention of recurrent stroke.

Methods: Search in Medline (PubMed) and in ISI Web of Knowledge. Parameters under analysis and meta-analyses were: stroke, transient ischemic attack (TIA) and atrial fibrillation (AF). Comprehensive Meta-analysis Software V.2.0 (Biostat) was used. Random-effects analyses were carried out. A level of significance of 5\% was used.

Results: In this study six, randomized trials enrolling 3,750 patients were included. Unlike other published metaanalyses on the same topic, in this case, only clinical trial data, and not follow-up data, were used. PFO closure, as compared with medical therapy alone, demonstrated superiority in reducing the rate of recurrent stroke (risk ratio with PFO closure vs. medical therapy, $0.37 ; 95 \%$ confidence interval $[\mathrm{CI}], 0.17$ to $0.78 ; \mathrm{p}=0.01$ ). PFO closure did not offer a significant benefit in prevention of TIA (risk ratio with PFO closure vs. medical therapy, 0.96; 95\% CI, 0.64 to $1.44 ; \mathrm{p}=0.85$ ). Among patients assigned to closure group, an increased risk of atrial fibrillation was seen (risk ratio with PFO closure vs. medical therapy, 4.64; 95\% CI, 2.38 to 9.01; $\mathrm{p}<0.01$ ).

Conclusions: In patients with cryptogenic stroke who had a patent foramen ovale, a protective effect of closure was seen concerning the risk of recurrent stroke, but not regarding the prevention of TIA. (Int J Cardiovasc Sci. 2020; 33(4):307-317)

Keywords: Foramen Ovale Patent/Diagnosis; Stroke; Isquemic Attack, Transient; Atrial Fibrillation; Risk Factors; Stroke/Prevention and control.

\section{Introduction}

Stroke remains one of the most important causes of death and morbidity worldwide. ${ }^{1}$ Between $20 \%$ and $30 \%$ of ischemic strokes have no identifiable cause after exclusion of all potential causes, and they are denominated cryptogenic strokes. ${ }^{2}$ Forty to fifty percent of patients who suffer a cryptogenic stroke also have a patent foramen ovale (PFO). This association suggests that some cryptogenic strokes, particularly in younger patients, may be due to paradoxical embolism, which consists in the passage of a thrombus from the venous to the atrial system through a patent foramen ovale. ${ }^{3,4}$

The options to implement secondary prevention of recurrent stroke for patients with a patent foramen ovale who have had a cryptogenic stroke have been the administration of antithrombotic medications or percutaneous closure of PFO. However, it was not initially clear whether percutaneous closure is superior to medical therapy. ${ }^{5,6}$ The results of early studies gave

Mailing Address: Sónia P. P. Pereira

Faculdade de Medicina, Universidade do Porto, Alameda Prof. Hernani Monteiro. Postal Code: 4200-319, Porto - Portugal.

E-mail: sonia_1995@live.com.pt 
no room for excessive optimism. These relatively modest results have been attributed to the choice of closure device, off-protocol closure device use within the medical therapy arms, patient selection criteria and slow enrolment, ${ }^{1,3,5,7,8}$ among other reasons.

In the years 2017 and 2018, three new clinical trials were published, which demonstrated that percutaneous PFO closure, as compared with medical therapy, does reduce the risk of recurrent stroke. ${ }^{6,9,10}$ Some of these results, impressive as they are, have been obtained by the selective inclusion of patients with high-risk PFO features, including the size of the patent foramen ovale, or the presence of an atrial septal aneurysm, making PFO closure particularly persuasive in these patients. However, restricting device closure entirely to patients with high-risk characteristics of PFO may be too conservative. ${ }^{11}$

Concerning the clinical trials currently published, several meta-analyses were carried out, ${ }^{12-19}$ but all of them include data from a follow-up study ${ }^{2}$ rather than the original clinical trial data, that is, data that the authors themselves considered to be exploratory.

The purpose of the present study was to produce an updated meta-analysis including only data from the primary analyses of clinical trials evaluating the role of PFO closure in the secondary prevention of recurrent stroke, since several texts previously published contained data from both original clinical trials and a follow up study.

\section{Methods}

\section{Search strategy}

The study started with a search on Medline (PubMed) database, using the query "patent foramen ovale" AND "stroke" AND "closure" with the filter "clinical trial". The search took place on July 2018, and no articles were excluded based on publication date. The search yielded 40 articles. A further search was carried out in a second database, ISI Web of Knowledge, using the same query, with the filter "article", on December 2018, yielding 840 articles (Figure 1, supplementary file 1). Additional studies were found after searching the references of previous review articles and other relevant sources, including articles related to the topic in question as well as articles citing the selected articles.

\section{Inclusion criteria}

Only human studies were included, and only interventional studies comparing PFO closure with medical therapy were considered within the scope of this review.

\section{Exclusion criteria}

The following were excluded: mechanistic studies, animal studies, studies of PFO physiology, case reports, editorials, review papers, study protocols, non-randomized studies, duplicate studies (if found), systematic reviews and/or meta-analyses, sub-group analyses of included studies, follow-up data of included studies, cost analyses or surveys, comparison between medical treatments, comparison between closure devices, studies on PFO closure only, guidelines, genetic and pathological studies.

\section{Statistical analysis}

We aimed at presenting an overview of clinical trials evaluating interventional studies comparing PFO closure with medical therapy. The meta-analysis was carried out by using the Comprehensive Meta-analysis Software V.2.0 (Biostat, New Jersey, USA). Randomeffects analyses were carried out, given the considerable heterogeneity of some of the data. The parameters chosen for analysis and also for the meta-analyses were: stroke, transient ischemic attack and atrial fibrillation. Risk ratios were calculated. A level of significance of $5 \%$ was used. Results were reviewed by a biostatistician (CS).

\section{Quality assessment of studies and data extraction}

Study quality and eligibility were independently assessed by two researchers. Different opinions regarding the relevance of articles were solved by consensus between the authors. Global article quality assessment was carried out according to the method used by Haffar and colleagues (supplementary file 2). ${ }^{20}$

\section{Results}

A total of six articles were identified and selected for further study. ${ }^{3,5,6,8-10}$ Interobserver agreement was $100 \%$. Between 2012 and 2018, six randomized controlled trials (RCTs) comparing closure of PFO with medical 


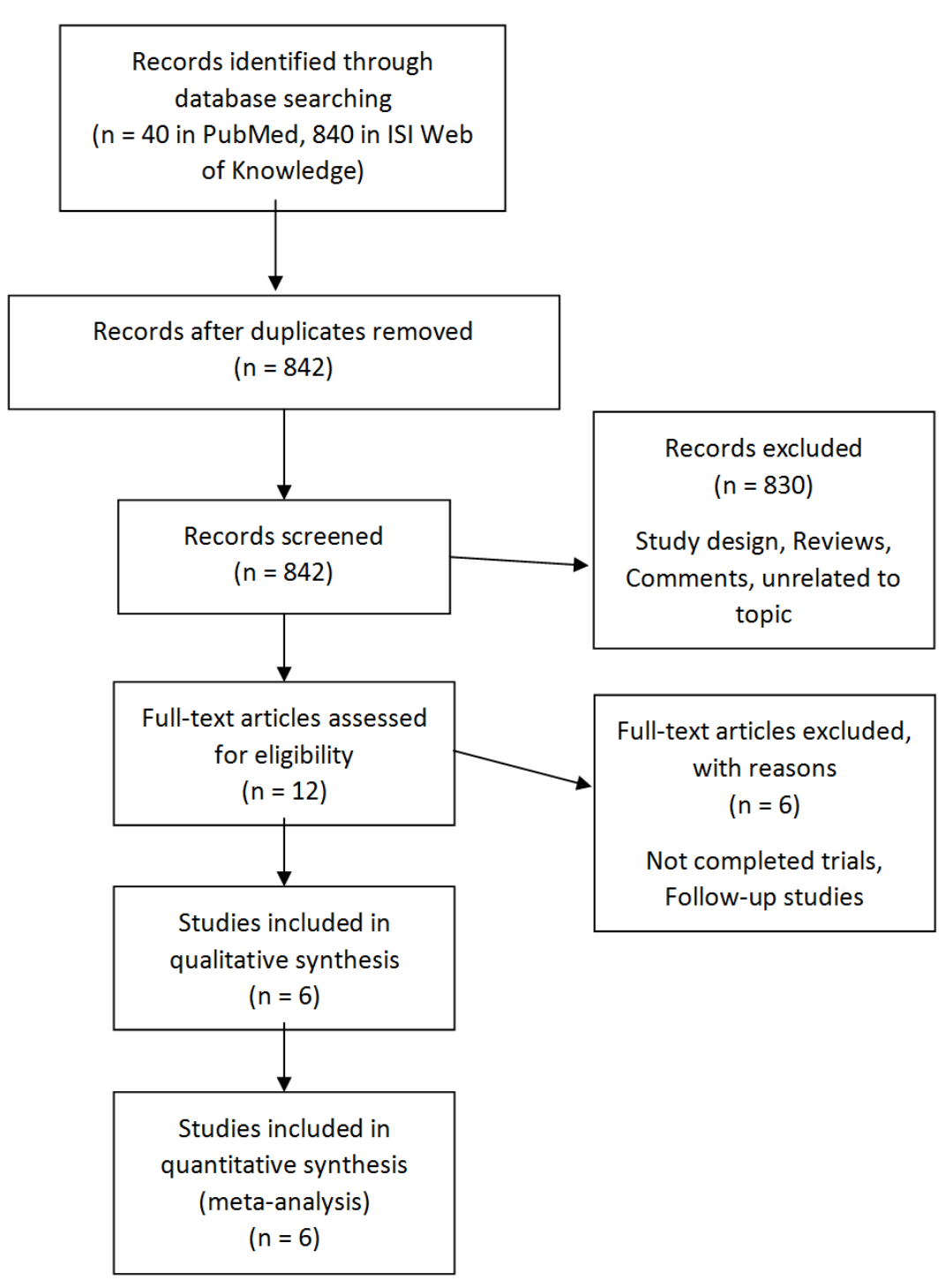

Figure 1 - Flow Diagram of Studies selection.

therapy alone for secondary prevention of patients with cryptogenic stroke and patent foramen ovale were published. These studies involved a total of 3,750 patients who were randomly assigned to either closure with the percutaneous device (closure group) or medical therapy alone (medical-therapy group). Concerning the acronyms, CLOSURE 1 denotes "Evaluation of the STARFlex Septal Closure System in Patients with a Stroke and/or Transient Ischemic Attack due to Presumed Paradoxical Embolism through a Patent Foramen Ovale", RESPECT "Randomized Evaluation of Recurrent Stroke Comparing PFO Closure to Established Current
Standard of Care Treatment", PC trial "Clinical Trial Comparing Percutaneous Closure of Patent Foramen Ovale (PFO) using the Amplatzer PFO Occluder with Medical Treatment in Patients with Cryptogenic Embolism”, CLOSE "Patent Foramen Ovale Closure or Anticoagulants versus Antiplatelet Therapy to Prevent Stroke Recurrence", REDUCE "GORE HELEX Septal Occluder / GORE CARDIOFORM Septal Occluder and Antiplatelet Medical Management for Reduction of Recurrent Stroke or Imaging-Confirmed TIA in Patients with Patent Foramen Ovale (PFO) - The Gore REDUCE Clinical Study”, DEFENSE PFO “Device Closure Versus 
Medical Therapy for Cryptogenic Stroke Patients with High-Risk Patent Foramen Ovale"). The main aspects of the selected studies are shown in Table 1. In the closure group, device implantation was performed soon after randomization and, after the procedure, all patients were given antithrombotic therapy at the discretion of the site investigator, but always in accordance with the guideline recommendations. The mean follow-up duration varied between RCTs from 2 to 5.3 years.

The data of patients enrolled in each RCT are listed in Table 2. After randomization, a total of 1,889 patients were assigned to closure arm and 1,671 patients were assigned

Table 1 - The main aspects of selected studies

\begin{tabular}{|c|c|c|c|c|c|c|c|}
\hline & $\begin{array}{c}\text { Total } \\
\text { number of } \\
\text { patients }\end{array}$ & $\begin{array}{l}\text { Inclusion } \\
\text { criteria }\end{array}$ & $\begin{array}{c}\text { Device and } \\
\text { additional therapy }\end{array}$ & $\begin{array}{l}\text { Medical } \\
\text { therapy }\end{array}$ & $\begin{array}{c}\text { Follow-up } \\
\text { duration } \\
\text { (years) }\end{array}$ & $\begin{array}{l}\text { Primary } \\
\text { outcomes }\end{array}$ & $\begin{array}{c}\text { Level of } \\
\text { significance } \\
\text { adopted }\end{array}$ \\
\hline $\begin{array}{l}\text { CLOSURE } \\
1 \text { (2012) }\end{array}$ & 909 & $\begin{array}{c}\text { 1. } 18 \text { to } 60 \mathrm{y} \\
\text { of age } \\
\text { 2. PFO } \\
\text { documented } \\
\text { on TE } \\
\text { 3. CS or TIA } \\
\text { within the } \\
\text { previous } 6 \text { mo }\end{array}$ & $\begin{array}{c}\text { STARFLex } \\
\text { Septal Closure } \\
\text { System + } \\
\text { clopidogrel } 75 \mathrm{mg} / \\
\text { day, } 6 \text { months, + } \\
\text { aspirin, } 81 \text { or } 325 \\
\text { mg/day, } 2 \text { years }\end{array}$ & Aspirin or warfarin or both & 2 & $\begin{array}{l}\text { A composite } \\
\text { of stroke or } \\
\text { TIA }<2 \text { y and } \\
\text { death (death } \\
\text { for any cause } \\
<30 \text { d or death } \\
\text { for neurologic } \\
\text { causes between } \\
31 \mathrm{~d} \text { and } 2 \mathrm{y} \text { ) }\end{array}$ & $5 \%$ \\
\hline $\begin{array}{l}\text { PC TRIAL } \\
(2013)\end{array}$ & 414 & $\begin{array}{c}\text { 1. }<60 \text { y of } \\
\text { age } \\
\text { 2. PFO } \\
\text { documented } \\
\text { on TE } \\
\text { 3. CS, TIA } \\
\text { with cerebral } \\
\text { ischemic } \\
\text { lesion, or PTE }\end{array}$ & $\begin{array}{c}\text { Amplatzer PFO } \\
\text { Occluder + 100-325 } \\
\text { mg/day aspirin } \\
\text { for at least } 5 \text { to } 6 \\
\text { months + either } \\
250-500 \mathrm{mg} / \mathrm{d} \\
\text { ticlopidine or } 75-150 \\
\text { mg/day clopidogrel } \\
\text { for } 1 \text { to } 6 \text { months }\end{array}$ & $\begin{array}{l}\text { Antiplatelet therapy or oral } \\
\text { anticoagulation }\end{array}$ & $\begin{array}{c}\text { Mean: } \\
4.1^{\mathrm{a}} \\
4.0^{\mathrm{b}}\end{array}$ & $\begin{array}{l}\text { A composite of } \\
\text { death, nonfatal } \\
\text { stroke, TIA } \\
\text { or peripheral } \\
\text { embolism }\end{array}$ & $5 \%$ \\
\hline $\begin{array}{l}\text { CLOSE } \\
(2017)\end{array}$ & 663 & $\begin{array}{l}\text { 1. } 16 \text { to } 60 \mathrm{y} \\
\text { of age } \\
\text { 2. PFO with } \\
\text { atrial septal } \\
\text { aneurysm } \\
\text { or large } \\
\text { interatrial } \\
\text { shunt } \\
\text { 3. CS within } \\
\text { the previous } \\
6 \text { mo }\end{array}$ & $\begin{array}{l}\text { One randomization } \\
\text { arm: any of eleven } \\
\text { different devices } \\
\text { + dual antiplatelet } \\
\text { therapy (75 mg of } \\
\text { aspirin plus } 75 \mathrm{mg} \\
\text { of clopidogrel per } \\
\text { day) for } 3 \text { months, } \\
\text { followed by single } \\
\text { antiplatelet therapy } \\
\text { throughout the } \\
\text { remainder of the } \\
\text { trial }\end{array}$ & $\begin{array}{l}\text { Two further randomization } \\
\text { arms: antiplatelet therapy } \\
\text { alone (antiplatelet-only } \\
\text { group), or oral anticoagulation } \\
\text { (anticoagulation group). } \\
\text { Antiplatelet regimen: } \\
\text { aspirin, clopidogrel, or } \\
\text { aspirin combined with ER- } \\
\text { dipyridamole. } \\
\text { Patients with contraindications } \\
\text { to anticoagulants or to PFO } \\
\text { closure were randomly } \\
\text { assigned to the alternative } \\
\text { noncontraindicated treatment } \\
\text { or to antiplatelet therapy }\end{array}$ & $\begin{array}{l}\text { Mean: } \\
5.3 \pm 2.0\end{array}$ & $\begin{array}{c}\text { Fatal or } \\
\text { nonfatal } \\
\text { stroke. }\end{array}$ & $5 \%$ \\
\hline
\end{tabular}




\begin{tabular}{|c|c|c|c|c|c|c|c|}
\hline & $\begin{array}{l}\text { Total } \\
\text { number of } \\
\text { patients }\end{array}$ & $\begin{array}{l}\text { Inclusion } \\
\text { criteria }\end{array}$ & $\begin{array}{l}\text { Device and } \\
\text { additional therapy }\end{array}$ & $\begin{array}{l}\text { Medical } \\
\text { therapy }\end{array}$ & $\begin{array}{l}\text { Follow-up } \\
\text { duration } \\
\text { (years) }\end{array}$ & $\begin{array}{l}\text { Primary } \\
\text { outcomes }\end{array}$ & $\begin{array}{l}\text { Level of } \\
\text { significance } \\
\text { adopted }\end{array}$ \\
\hline $\begin{array}{l}\text { REDUCE } \\
(2017)\end{array}$ & 664 & $\begin{array}{l}1.18 \text { to } 59 \mathrm{y} \\
\text { of age } \\
\text { 2. PFO } \\
\text { documented } \\
\text { on TE } \\
\text { 3.CS within } \\
\text { the previous } \\
180 \text { days }\end{array}$ & $\begin{array}{l}\text { Helex Septal } \\
\text { Occluder or } \\
\text { Cardioform } \\
\text { Septal Occluder } \\
+ \text { Antiplatelet } \\
\text { therapy as in the } \\
\text { medical therapy } \\
\text { arm + clopidogrel } \\
\text { at the time of the } \\
\text { procedure and for } \\
3 \text { days }\end{array}$ & $\begin{array}{c}75-325 \text { mg/day aspirin or 50- } \\
100 \text { mg/day Aspirin + 225-400 } \\
\text { mg/day dipyridamole or } \\
75 \text { mg/day clopidogrel }\end{array}$ & $\begin{array}{l}\text { Mean: } \\
3.2\end{array}$ & $\begin{array}{l}\text { Two coprimary } \\
\text { end points } \\
\text { of clinical } \\
\text { ischemic stroke } \\
\text { and new brain } \\
\text { infarction }\end{array}$ & $5 \%$ \\
\hline $\begin{array}{l}\text { DEFENSE } \\
\text { PFO (2018) }\end{array}$ & 120 & $\begin{array}{l}\text { 1. High-risk } \\
\text { PFO - PFO } \\
\text { with atrial } \\
\text { septal } \\
\text { aneurysm, } \\
\text { hypermobility } \\
\text { (phasic septal } \\
\text { excursion into } \\
\text { either atrium } \\
\geq 10 \text { mm), } \\
\text { or PFO size } \\
\text { (maximum } \\
\text { separation of } \\
\text { the septum } \\
\text { primum } \\
\text { from the } \\
\text { secundum) } \\
\geq 2 \text { mm } \\
\text { 2. CS within } \\
\text { the previous } \\
6 \text { mo }\end{array}$ & $\begin{array}{l}\text { Amplatzer PFO } \\
\text { Occluder + dual } \\
\text { antiplatelet regimen } \\
\text { (aspirin } 100 \mathrm{mg} / \\
\text { day in combination } \\
\text { with clopidogrel } \\
75 \mathrm{mg} / \text { day) for at } \\
\text { least } 6 \text { months; } \\
\text { anticoagulation } \\
\text { therapy allowed as } \\
\text { alternative }\end{array}$ & $\begin{array}{c}\text { Aspirin or aspirin + clopidogrel } \\
\text { or aspirin }+ \text { cilostazol or } \\
\text { warfarin }\end{array}$ & $\begin{array}{c}\text { Median: } \\
2.8\end{array}$ & $\begin{array}{c}\text { Composite } \\
\text { of stroke, } \\
\text { vascular death, } \\
\text { or major } \\
\text { bleeding }\end{array}$ & $5 \%$ \\
\hline
\end{tabular}

A: closure group; B: medical therapy group; PFO: patent foramen ovale; TE: transesophageal echocardiography; CS: cryptogenic ischemic stroke; TIA: transient ischemic attack; PTE: peripheral thromboembolic event; D: days; Mo: month; Y: years; ER: extended-release; Aspirin: acetylsalicylic acid. For acronyms see text.

to medical therapy arm. The mean age was 46 years in both groups. Furthermore, dropouts were observed in each study and similar rate of serious adverse events were seen between the two treatment arms. Efficacy and safety endpoints are illustrated in Table 3.

The clinical endpoints under evaluation in the present report were: stroke, transient ischemic attack and incidence of atrial fibrillation during the followup period.

When compared to medical treatment only, PFO closure significantly reduced the rate of recurrent stroke (risk ratio, $0.37 ; 95 \%$ confidence interval $[\mathrm{CI}], 0.17$ to 0.78 ; $\mathrm{p}=0.01$; I squared 51.12; Figure 2).

However, PFO closure did not offer any significant benefit in the prevention of TIA (risk ratio, $0.96 ; 95 \% \mathrm{CI}$, 0.64 to $1.44 ; \mathrm{p}=0.85$; I squared 0.00; Figure 3 ).

Each study demonstrated a relatively low frequency of device and procedure-related complications. PFO closure increased the risk of atrial fibrillation (risk ratio with PFO closure, 4.64; 95\% CI, 2.38 to 9.01; $\mathrm{p}<0.01$; I squared 3.84, Figure 4). Importantly, in most cases, AF was periprocedural. 
Table 2 - Data concerning number of patients, mean age, dropouts and serious adverse events of patients enrolled in each study. For acronyms see text

\begin{tabular}{|c|c|c|c|c|c|c|c|c|}
\hline & \multicolumn{2}{|c|}{ Number of patients } & \multicolumn{2}{|c|}{ Mean age (years) } & \multicolumn{2}{|c|}{$\begin{array}{c}\text { Dropouts (number of } \\
\text { patients) }\end{array}$} & \multicolumn{2}{|c|}{$\begin{array}{c}\text { Serious adverse events } \\
\qquad(\%)\end{array}$} \\
\hline & Closure & Control & Closure & Control & Closure & Control & Closure & Control \\
\hline CLOSURE 1 & 447 & 462 & $46.3 \pm 9.6$ & $45.7 \pm 9.1$ & 69 & 87 & 16.9 & 16.6 \\
\hline RESPECT & 499 & 481 & $45.7 \pm 9.7$ & $46.2 \pm 10.0$ & 46 & 83 & 23.0 & 21.6 \\
\hline PC TRIAL & 204 & 210 & $44.3 \pm 10.2$ & $44.6 \pm 10.1$ & 31 & 42 & 21.1 & 17.6 \\
\hline CLOSE & 238 & 235 & $42.9 \pm 10.1$ & $43.8 \pm 10.5$ & 21 & 12 & 35.7 & 33.2 \\
\hline REDUCE & 441 & 223 & $45.4 \pm 9.3$ & $44.8 \pm 9.6$ & 39 & 33 & 23.1 & 27.8 \\
\hline DEFENSE PFO & 60 & 60 & $49 \pm 15$ & $54 \pm 12$ & - & - & - & - \\
\hline
\end{tabular}

Table 3 - Data concerning stroke, transient ischemic attack (TIA) and atrial fibrillation (AF), in patients involved in trials comparing closure of patent foramen ovale versus medical therapy (total number of patients in brackets). For acronyms see text

\begin{tabular}{|c|c|c|c|c|c|c|}
\hline & \multicolumn{2}{|c|}{ Stroke } & \multicolumn{2}{|c|}{ TIA } & \multicolumn{2}{|c|}{$\mathbf{A F}$} \\
\hline & Closure & Control & Closure & Control & Closure & Control \\
\hline CLOSURE 1 & $12(447)$ & $13(462)$ & $13(447)$ & $17(462)$ & $23(402)$ & $3(458)$ \\
\hline RESPECT & $9(499)$ & $16(481)$ & $6(499)$ & $4(481)$ & $3(499)$ & $3(481)$ \\
\hline PC TRIAL & $1(204)$ & $5(210)$ & $5(204)$ & $7(210)$ & $6(204)$ & $2(210)$ \\
\hline CLOSE & $0(238)$ & $14(235)$ & $8(238)$ & $8(235)$ & $11(238)$ & $2(235)$ \\
\hline REDUCE & $6(441)$ & $12(223)$ & $21(441)$ & $8(223)$ & $29(441)$ & $1(223)$ \\
\hline DEFENSE PFO & $0(60)$ & $5(60)$ & $0(60)$ & $1(60)$ & $2(60)$ & $0(60)$ \\
\hline
\end{tabular}

Data on risk difference and annualized risk difference concerning the three outcomes under evaluation are presented in supplementary file 2 .

\section{Discussion}

Controversy has persisted after the first reports were published on whether PFO closure reduces the risk of recurrent stroke for patients with cryptogenic stroke and documented PFO, when compared with medical therapy. Since 2012, six randomized controlled trials were published with the aim of comparing these two forms of secondary prevention. ${ }^{3,5,6,8-10}$ In the present updated meta-analysis, transcatheter PFO closure in cryptogenic strokes was shown to be superior to medical therapy in reducing recurrent stroke, although the risk of TIA was similar between the two groups. We also confirmed that patients who underwent transcatheter closure were more likely to develop transient atrial fibrillation as compared with the medical-therapy group. Our findings are in line with the results of recent meta-analyses, ${ }^{12-19}$ However, the present study includes data of the RESPECT trial published in 2013, as opposed to recent meta-analyses, which selected the RESPECT long-term results, published in 2017, and therefore are not the primary results of a controlled trial, but rather a follow-up study.

All six studies included young to middle-age patients with PFO documented on transesophageal echocardiography (TE) and cryptogenic stroke, usually in the six months prior to randomization.

Three randomized controlled trials (RCTs) conducted earlier, which were published in 2012 and 2013, failed 


\begin{tabular}{lllllll}
\cline { 5 - 6 } Study name & & \multicolumn{5}{c}{ Statistics for each study } \\
\cline { 5 - 6 } & & $\begin{array}{c}\text { Risk } \\
\text { ratio }\end{array}$ & $\begin{array}{c}\text { Lower } \\
\text { limit }\end{array}$ & $\begin{array}{l}\text { Upper } \\
\text { limit }\end{array}$ & Z-Value & p-Value \\
Closure 1 & 0,954 & 0,440 & 2,068 & $-0,119$ & 0,905 \\
Respect & 0,542 & 0,242 & 1,215 & $-1,487$ & 0,137 \\
PC Trial & 0,206 & 0,024 & 1,747 & $-1,449$ & 0,147 \\
Close & 0,034 & 0,002 & 0,568 & $-2,355$ & 0,019 \\
Reduce & 0,253 & 0,096 & 0,665 & $-2,788$ & 0,005 \\
Defense PFO & 0,091 & 0,005 & 1,609 & $-1,636$ & 0,102 \\
& 0,366 & 0,171 & 0,782 & $-2,592$ & 0,010
\end{tabular}

Study name

Statistics for each study

Risk ratio and $95 \% \mathrm{Cl}$

$\begin{array}{lcccrrr} & \begin{array}{c}\text { Risk } \\ \text { ratio }\end{array} & \begin{array}{c}\text { Lower } \\ \text { limit }\end{array} & \begin{array}{c}\text { Upper } \\ \text { limit }\end{array} & \text { Z-Value } & \text { p-Value } \\ \text { Closure } 1 & 0,790 & 0,388 & 1,608 & -0,649 & 0,516 \\ \text { Respect } & 1,446 & 0,411 & 5,092 & 0,574 & 0,566 \\ \text { PC Trial } & 0,735 & 0,237 & 2,279 & -0,533 & 0,594 \\ \text { Close } & 0,987 & 0,377 & 2,587 & -0,026 & 0,979 \\ \text { Reduce } & 1,264 & 0,566 & 2,825 & 0,571 & 0,568 \\ \text { Defense PFO } & 0,333 & 0,014 & 8,023 & -0,677 & 0,498 \\ & 0,963 & 0,642 & 1,442 & -0,185 & 0,853\end{array}$

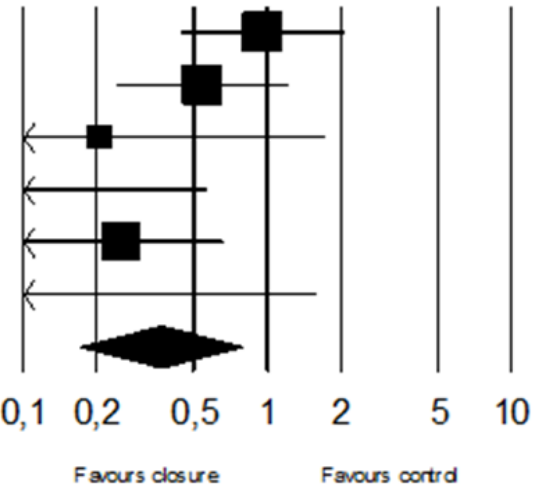

Farours dosure 
Study name

\begin{tabular}{|c|c|c|c|c|c|}
\hline & $\begin{array}{l}\text { Risk } \\
\text { ratio }\end{array}$ & $\begin{array}{l}\text { Lower } \\
\text { limit }\end{array}$ & $\begin{array}{l}\text { Upper } \\
\text { limit }\end{array}$ & Z-Value & $\mathrm{p}$-Value \\
\hline Closure 1 & 7,924 & 2,396 & 26,205 & 3,392 & 0,001 \\
\hline Respect & 1,285 & 0,289 & 5,712 & 0,330 & 0,74 \\
\hline PCTrial & 3,088 & 0,631 & 15,124 & 1,391 & \\
\hline Close & 5,431 & 1,217 & 24,237 & 2,217 & \\
\hline Reduce & 14,664 & 2,011 & 106,952 & 2,649 & \\
\hline \multirow[t]{2}{*}{ Defense PFO } & 5,000 & 0,245 & 102,002 & 1,046 & \\
\hline & 4,644 & 2,381 & 9,056 & 4,506 & \\
\hline
\end{tabular}

Figure 4 - Risk Ratios for atrial fibrillation in six major trials. CI: confidence interval. For references and trial acronyms, see text. patients with high-risk anatomic PFO features. Therefore, better and stricter patient selection in more recent RCTs may have increased the probability of having a stroke due to PFO and consequently may have increased the likelihood that PFO closure would be effective.

Patent foramen ovale presumably provides an anatomic substrate for paradoxical embolism, which may be the cause of most of the cryptogenic strokes. ${ }^{21}$ Our findings confirm that PFO closure significantly decreased the rate of recurrent ischemic stroke. The risk of TIA, however, was unaltered, pointing in the direction of a different pathophysiology of TIA in this setting (possibly unrelated to paradoxical embolism) and the potential misclassification of non-ischemic events as TIA. Each study demonstrated low frequency of device and procedure-related complications but a significant increase of $\mathrm{AF}$ in the interventional group was seen, which could in theory increase the risk of recurrent stroke. However, most cases of atrial fibrillation occurred early after the procedure with no recurrence during follow-up.

The key to an appropriate treatment strategy could be to detect which patients may derive more benefit from PFO closure. Recent studies have shown some characteristics that increase the potential benefit for the patient, but more studies are needed to clarify this issue. $^{22}$ The decision to choose a given type of treatment should be multidisciplinary and shared with the patient, considering the preferences of each person.

The major sources of data heterogeneity are presented in Table 1 - differences in inclusion criteria, in device used, in medical therapy, and in mean follow-up. Patients requiring long-term anticoagulation therapy were mostly excluded from the clinical trials. Thus, the population of patients under anticoagulation therapy does not seem to have a proven benefit with $\mathrm{PFO}$ closure for the time being.

\section{Limitations}

The studies included were all open label and not double blind, which might impact the results with differential evaluation of suspected events and unequal referral of those events to the adjudication committees. As stated above, there was non-uniformity in the followup period, patients' characteristics, inclusion criteria and closure device used between the studies included. TIA was only a primary endpoint in two of the clinical trials, namely, PC trial and CLOSURE I trial.

Preference of some patients and physicians prompted a differential dropout of studies and crossovers between the two treatment groups that may have biased the trials results. Thus, PFO closure was not performed in all patients initially assigned and not all patients who underwent the procedure had a successful closure. 
If residual shunts persisted, this might mask the real efficacy of PFO closure in the prevention of recurrent strokes. Similarly, some patients of medical group underwent PFO closure with devices approved by the Food and Drug Administration (FDA) for other indications (off-label use).

In the medical therapy groups, there was lack of standardization in the type and doses of the medical therapy used in each site and the use of anticoagulant treatment was more frequent as compared with the closure group. In addition, discontinuation of antithrombotic treatment was allowed after PFO closure in many trials, which may have increased the risk of non-PFO-related stroke in these studies. Finally, the definitions used for reporting atrial fibrillation varied among trials and may not be directly comparable.

\section{Conclusions}

At the present stage, patent foramen ovale closure seems to be superior to medical treatment in reducing recurrent stroke in patients with cryptogenic stroke. Comparable risks of TIA for both strategies have been seen in the studies published so far. Furthermore, even though a significantly higher risk of new-onset atrial fibrillation was seen with closure, studies suggested that it was usually periprocedural. These findings suggest that PFO closure is a better strategy for secondary prevention of recurrent stroke in patients with a cryptogenic stroke and patent foramen ovale.

\section{Author contributions}

Conception and design of the research: all authors. Acquisition of data: SPPP, AN. Analysis and interpretation of the data: all authors. Statistical analysis: JPLN, CS. Writing of the manuscript: all authors. Critical revision of the manuscript for intellectual content: all authors

\section{Potential Conflict of Interest}

No potential conflict of interest relevant to this article was reported.

\section{Sources of Funding}

There were no external funding sources for this study.

\section{Study Association}

This study is associated with the master thesis of the first author.

\section{Ethics approval and consent to participate}

This article does not contain any studies with human participants or animals performed by any of the authors.

\section{References}

1. Feldman DN, Weinberger J, Elmariah S. Device Closure of Patent Foramen Ovale in Patients With Cryptogenic Stroke: The Tide Has Turned*. J Am Coll Cardiol. 2018;71(20):2343-5.

2. Saver JL, Carroll JD, Thaler DE, Smalling RW, MacDonald LA, Marks DS, et al. Long-Term Outcomes of Patent Foramen Ovale Closure or Medical Therapy after Stroke. N Engl J Med. 2017;377(11):1022-32.

3. Furlan AJ, Reisman M, Massaro J, Mauri L, Adams H, Albers GW, et al. Closure or Medical Therapy for Cryptogenic Stroke with Patent Foramen Ovale. N Engl J Med. 2012;366(11):991-9.

4. Mojadidi MK, Zaman MO, Elgendy IY, Mahmoud AN, Patel NK, Agarwal $\mathrm{N}$, et al. Cryptogenic Stroke and Patent Foramen Ovale. J Am Coll Cardiol. 2018;71(9):1035-43.

5. Meier B, Kalesan B, Mattle HP, Khattab AA, Hildick-Smith D, Dudek D, et al. Percutaneous Closure of Patent Foramen Ovale in Cryptogenic Embolism. N Engl J Med. 2013;368(12):1083-91.

6. Søndergaard L, Kasner SE, Rhodes JF, Andersen G, Iversen HK, NielsenKudsk JE, et al. Patent Foramen Ovale Closure or Antiplatelet Therapy for Cryptogenic Stroke. N Engl J Med. 2017;377(11):1033-42.

7. Farb A, Ibrahim NG, Zuckerman BD. Patent Foramen Ovale after Cryptogenic Stroke - Assessing the Evidence for Closure. N Engl J Med. 2017;377(11):1006-9.

8. Carroll JD, Saver JL, Thaler DE, Smalling RW, Berry S, MacDonald LA, et al. Closure of Patent Foramen Ovale versus Medical Therapy after Cryptogenic Stroke. N Engl J Med. 2013;368(12):1092-100.

9. Mas J-L, Derumeaux G, Guillon B, Massardier E, Hosseini H, Mechtouff L, et al. Patent Foramen Ovale Closure or Anticoagulation vs. Antiplatelets after Stroke. N Engl J Med. 2017;377(11):1011-21.

10. Lee PH, Song J-K, Kim JS, Heo R, Lee S, Kim D-H, et al. Cryptogenic Stroke and High-Risk Patent Foramen Ovale. The DEFENSE-PFO Trial. J Am Coll Cardiol. 2018;71(20):2335-42.

11. Ropper AH. Tipping Point for Patent Foramen Ovale Closure. N Engl J Med. 2017;377(11):1093-5.

12. Vidale S, Russo F, Campana C, Agostoni E. Patent Foramen Ovale Closure Versus Medical Therapy in Cryptogenic Strokes and Transient Ischemic Attacks: A Meta-Analysis of Randomized Trials. Angiology.2019;70(4):325-31.

13. Lai J, Tse G, Wu W, Gong M, Bazoukis G, Wong W, et al. Patent foramen ovale closure versus medical therapy for stroke prevention: A systematic review and meta-analysis of randomized controlled trials [Version 2; referees: 2 approved]. F1000Research. 2018;6(2178).

14. Sitwala P, Khalid MF, Khattak F, Bagai J, Bhogal S, Ladia V, et al Percutaneous closure of patent foramen ovale in patients with 
cryptogenic stroke - An updated comprehensive meta-analysis. Cardiovasc Revascular Med. 2019;20(8):687-94

15. Ma Y, Li D, Bai F, Qin F, Li J, Li Y, et al. Patent foramen ovale closure or medical therapy for secondary prevention of cryptogenic stroke: An update meta-analysis of randomized controlled trials. Medicine (Baltimore). 2018;97(34):e11965.

16. Vukadinovic D, Schirmer SH, Vukadinovic AN, Ukena C, Scheller B, Mahfoud F, et al. Interventional closure vs. medical therapy of patent foramen ovale for secondary prevention of stroke: updated meta-analysis. Clin Res Cardiol. 2019;108(2):157-66

17. Qiu B, Cai Y, Wang D, Lin J, Fan Y. Closure versus Medical Therapy for Patent Foramen Ovale in Patients with Cryptogenic Stroke: An Updated Meta-Analysis of Randomized Controlled Trials. J Stroke Cerebrovasc Dis. 2018;27(12):3463-72.

18. Lattanzi S, Brigo F, Cagnetti C, Di Napoli M, Silvestrini M. Patent Foramen Ovale and Cryptogenic Stroke or Transient Ischemic Attack:
To Close or Not to Close? A Systematic Review and Meta-Analysis. Cerebrovasc Dis. 2018;45(5-6):193-203.

19. Turc G, Calvet D, Guerin P, Sroussi M, Chatellier G, Mas JL, et al. Closure, Anticoagulation, or Antiplatelet Therapy for Cryptogenic Stroke With Patent Foramen Ovale: Systematic Review of Randomized Trials, Sequential Meta-Analysis, and New Insights From the CLOSE Study. J Am Heart Assoc. 2018;7(12).piie00356

20. Haffar S, Shalimar, Kaur RJ, Wang Z, Prokop LJ, Murad MH, et al. Acute liver failure caused by hepatitis $\mathrm{E}$ virus genotype 3 and 4: A systematic review and pooled analysis. Liver Int. 2018;38(11):1965-73.

21. Hara H, Virmani R, Ladich E, Mackey-Bojack S, Titus J, Reisman M, et al. Patent Foramen Ovale: Current Pathology, Pathophysiology, and Clinical Status. J Am Coll Cardiol. 2005;46(9):1768-76.

22. Diener HC, Gerloff C, Thaler DE, Wohrle J. Closure of Patent Foramen Ovale and Cryptogenic Stroke: Unresolved Issues. Curr Neurol Neurosci Rep. 2018;18(12):92 


\section{Supplementary file 1}

Search strategy:

1. Medline (PubMed) database - query "patent foramen ovale" AND "stroke" AND "closure" with the filter "clinical trial".

2. ISI Web of Knowledge - query "patent foramen ovale" AND "stroke" AND "closure" with the filter "article".

\section{Supplementary file 2}

\begin{tabular}{|c|c|c|c|c|c|c|}
\hline Study & $\begin{array}{l}\text { Did the patient(s) } \\
\text { represent the } \\
\text { whole case(s) of the } \\
\text { medical center }\end{array}$ & $\begin{array}{l}\text { Was the } \\
\text { diagnosis } \\
\text { correctly } \\
\text { made }\end{array}$ & $\begin{array}{l}\text { Were other } \\
\text { important } \\
\text { diagnosis } \\
\text { excluded }\end{array}$ & $\begin{array}{c}\text { Were all } \\
\text { important } \\
\text { data cited in } \\
\text { the report }\end{array}$ & $\begin{array}{l}\text { Was the } \\
\text { outcome } \\
\text { correctly } \\
\text { ascertained }\end{array}$ & $\begin{array}{c}\text { Global } \\
\text { quality } \\
\text { assessment }\end{array}$ \\
\hline CLOSURE 1 & Yes & Yes & Yes & Yes & Yes & Good \\
\hline RESPECT & Yes & Yes & Yes & Yes & Yes & Good \\
\hline PC TRIAL & Yes & Yes & Yes & Yes & Yes & Good \\
\hline CLOSE & Yes & Yes & Yes & Yes & Yes & Good \\
\hline REDUCE & Yes & Yes & Yes & Yes & Yes & Good \\
\hline DEFENSE PFO & Yes & Yes & Yes & No & Yes & Moderate \\
\hline
\end{tabular}

Article quality assessment according to the method used by Haffar et al. For acronyms and complete references see text. 